\title{
Mediterranean and Black Sea Monstrilloid Copepods (Copepoda: Monstrilloida): Rediscovering the Diversity of Transient Zooplankters
}

\author{
Eduardo Suárez-Morales ${ }^{1, *}$ and Mark J. Grygier ${ }^{2}$ \\ 1 El Colegio de la Frontera Sur (ECOSUR), Chetumal 77014, Mexico \\ 2 Center of Excellence for the Oceans, National Taiwan Ocean University, No. 2, Beining Rd., \\ Zhongzheng Distr., Keelung 202301, Taiwan; thecostracans@gmail.com \\ * Correspondence: esuarez@ecosur.mx
}

Citation: Suárez-Morales, E.; Grygier, M.J. Mediterranean and Black Sea Monstrilloid Copepods (Copepoda: Monstrilloida): Rediscovering the Diversity of Transient Zooplankters. Water 2021 13, 1036. https://doi.org/10.3390/ w13081036

Academic Editor: Mirna Batistić

Received: 12 March 2021

Accepted: 2 April 2021

Published: 9 April 2021

Publisher's Note: MDPI stays neutra with regard to jurisdictional claims in published maps and institutional affiliations.

Copyright: (c) 2021 by the authors. Licensee MDPI, Basel, Switzerland. This article is an open access article distributed under the terms and conditions of the Creative Commons Attribution (CC BY) license (https:// creativecommons.org/licenses/by/ $4.0 /)$.

\begin{abstract}
Monstrilloids are copepods that live freely in plankton without feeding but have parasitic immature stages that develop within infected benthic molluscs and polychaetes. Because of their incompletely known life cycles and the difficulty of matching conspecific males and females, it has been difficult to assess their true diversity anywhere on earth. The monstrilloid fauna of the Mediterranean and Black seas (MBS) has been investigated for over 140 years, during which time four phases of study can be recognized. The initial list of MBS monstrilloids recorded during the first phase (1877-1893) grew only slowly for decades afterwards during the second phase (1895-1952) because of patchy sampling and a dearth of formal taxonomic descriptions. The third phase (19571986) featured little new work at all. During the most recent fourth phase since 1992, a reappraisal with heed to nomenclatural rules and upgraded descriptive standards has led to the realization that many nominal species of MBS monstrilloids are invalid or doubtful. Furthermore, some that have been frequently recorded, such as Monstrilla grandis, Cymbasoma longispinosum, and C. rigidum, may actually be undescribed representatives of widespread species groups. We provide an updated annotated checklist of MBS monstrilloids that includes 21 supposedly valid nominal species or species-groups. This rather high regional diversity will likely grow if future zooplankton surveys in the highly heterogeneous and extensive coastal systems of the MBS pay due attention to this intriguing group of copepods.
\end{abstract}

Keywords: zooplankton; monstrilloids; copepods; diversity; distribution

\section{Introduction}

Among the 10 currently recognized orders of Copepoda [1], the Calanoida comprise the most diverse and abundant group of marine zooplankton [2]. Calanoids are highly diverse in the Mediterranean Sea, where nearly 440 species have been recorded [3]; when considering the non-calanoid planktonic copepods as well, the number of species occurring there rises to more than $590[4,5]$.

The Monstrilloida, which are one of the least studied copepod orders, parasitize benthic molluscs and polychaetes as larvae while the better-known non-feeding and free-swimming adults can be found in plankton samples. Comprising the single family Monstrillidae, they appear to be most abundant and diverse in coastal habitats and over coral reefs [6,7]. The main aspects of their taxonomic diversity have been addressed $[7,8]$. Currently, the order and family are known to contain over 155 nominal species [4,7-9]) in seven valid genera $[10,11]$, although doubts about which genera are valid continue to be raised [12,13].

As a group, monstrilloids have been observed since the earliest marine planktological surveys carried out during the 19th century; their literature begins around 1845 [14]. 
Taxonomic exploration is still being done in different regions of the world, including previously unstudied areas like Australia [15,16] and Korea [12,13,17-20].

The Mediterranean-Black Sea (MBS) monstrilloid fauna has been considered among the best known worldwide [7]. The most up-to-date regional list [5] contains 28 nominal species in two genera. It partly reflects recent revisionary work conducted in accordance with current taxonomic and nomenclatural standards [11,21-28], but other records must still be reexamined. Here, we present an historical overview of monstrilloid studies in the MBS, comment on certain aspects of the reported diversity there, and provide a revised and updated regional checklist with annotations.

\section{Materials and Methods}

Based on a survey of the regional literature on Monstrilloida, for which several previous compendia (e.g., [4,5,14,29-31]) served as starting points, we divided the advance of knowledge about monstrilloid diversity and distribution in the MBS into four historical phases. Table 1 shows the additions of nominal species to the MBS monstrilloid inventory during these phases. The list of 21 species for the most recent, fourth phase excludes all invalid or doubtful earlier species records and indicates (as "cf.") those that might include undescribed members of species complexes; it thus serves as a revised and updated checklist of the MBS-inhabiting monstrilloids. In the following account, depending on context, generic assignments of the mentioned species are often updated (e.g., from invalid Thaumaleus to valid Cymbasoma), and their spellings are corrected, without comment. The generic abbreviation "M." is only used for Monstrilla, and "C." only for Cymbasoma.

Table 1. Original records of nominal species of monstrilloid copepods recorded from the Mediterranean and Black seas in primary and secondary literature during each of three historical phases of study (1877-1893, 1895-1952, 1957-1986), with a checklist of those currently accepted as valid plus additional species recorded since 1992. Spellings have been corrected. Species originally recorded as Thaumaleus are here listed as Cymbasoma, and all species of Caromiobenella were originally recorded as Monstrilla.

\begin{tabular}{|c|c|c|c|}
\hline Phase 1: 1877-1893 & Phase 2: 1895-1952 & Phase 3: 1957-1986 & $\begin{array}{c}\text { Phase 4: } 1992-2020 \text { (Current } \\
\text { Checklist) }\end{array}$ \\
\hline $\begin{array}{l}\text { Cymbasoma claparedii } \\
\text { C. herdmani }\end{array}$ & Cymbasoma claparedii & Cymbasoma longispinosum & $\begin{array}{l}\text { Cymbasoma clauderazoulsi } \\
\text { Suárez-Morales, Goruppi, de } \\
\text { Olazabal and Tirelli, } 2017\end{array}$ \\
\hline C. longispinosum & C. longispinosum & C. rigidum & C. cf. longispinosum (Bourne, 1890) \\
\hline C. reticulatum & C. rigidum & C. tenue & $\begin{array}{l}\text { C. mediterraneum Suárez-Morales, } \\
\text { Goruppi, de Olazabal and Tirelli, } 2017\end{array}$ \\
\hline C. rigidum & C. thompsonii & C. thompsonii & $\begin{array}{l}\text { C. nicolettae Suárez-Morales, } 2002 \\
\text { C. pseudobidentatum Suárez-Morales, } \\
\text { Goruppi, de Olazabal and Tirelli }\end{array}$ \\
\hline Monstrilla gracilicauda & Monstrilla gracilicauda & Monstrilla grandis & C. cf. rigidum Thompson, 1888 \\
\hline $\begin{array}{l}\text { M. intermedia (purported } \\
\text { synonym of } M . \text { grandis; } \\
\text { suppressed by ICZN) }\end{array}$ & $\begin{array}{l}\text { M. grandis (original source } \\
\text { of record unclear) }\end{array}$ & $\begin{array}{l}\text { M. leucopis (likely } \\
\text { erroneous) }\end{array}$ & C. reticulatum (Giesbrecht, 1893) \\
\hline M. longissima (nomen nudum) & M. helgolandica & M. longicornis & $\begin{array}{l}\text { C. sinopense Üstün, Terbiyik and } \\
\text { Suárez-Morales, } 1914\end{array}$ \\
\hline M. longiremis & $\begin{array}{l}\text { M. longicornis (original } \\
\text { source of record unclear) }\end{array}$ & M. longiremis & $\begin{array}{l}\text { C. specchii Suárez-Morales, Goruppi, } \\
\text { de Olazabal and Tirelli, } 2017\end{array}$ \\
\hline \multirow[t]{2}{*}{$\begin{array}{l}\text { M. pontica (insufficiently } \\
\text { known) }\end{array}$} & M. longiremis & $\begin{array}{l}\text { M. tumorifrons (nomen } \\
\text { nudum; later made } \\
\text { available) }\end{array}$ & $\begin{array}{l}\text { C. tenue (Isaac, 1975) } \\
\text { C. tergestinum Suárez-Morales, } \\
\text { Goruppi, de Olazabal and Tirelli }\end{array}$ \\
\hline & $\begin{array}{l}\text { M. ostroumowi (now in } \\
\text { Cymbasoma; possibly a } \\
\text { synonym of C. rigidum) }\end{array}$ & $\begin{array}{l}\text { Monstrillopsis angustipes } \\
\text { (nomen nudum) }\end{array}$ & $\begin{array}{l}\text { C. tumorifrons Suárez-Morales, } 1999 \\
\text { C. turcorum Suárez-Morales and } \\
\text { Üstün, } 2018\end{array}$ \\
\hline
\end{tabular}


Table 1. Cont.

\begin{tabular}{|c|c|c|c|}
\hline \multirow[t]{8}{*}{ Phase 1: 1877-1893 } & Phase 2: 1895-1952 & Phase 3: 1957-1986 & $\begin{array}{c}\text { Phase 4: 1992-2020 (Current } \\
\text { Checklist) }\end{array}$ \\
\hline & $\begin{array}{l}\text { M. serricornis (supposed } \\
\text { junior synonym of } M \text {. } \\
\text { helgolandica; original } \\
\text { source of record unclear) }\end{array}$ & & $\begin{array}{l}\text { Monstrilla ghirardellii Suárez-Morales, } \\
\text { Goruppi, de Olazabal and Tirelli, } 2017\end{array}$ \\
\hline & $\begin{array}{l}\text { Monstrillopsis dubia } \\
\text { (species complex; original } \\
\text { source of record unclear) }\end{array}$ & & M. grandis Giesbrecht, 1891 \\
\hline & $\begin{array}{l}\text { Monstrillopsis zernowi } \\
\text { (probably a Monstrilla) }\end{array}$ & & $\begin{array}{l}\text { M. longicornis Thompson, } 1890 \\
\text { M. longiremis Giesbrecht, } 1893\end{array}$ \\
\hline & & & $\begin{array}{l}\text { Monstrillopsis pontoeuxinensis } \\
\text { Suárez-Morales and Üstün, } 2018\end{array}$ \\
\hline & & & $\begin{array}{l}\text { Monstrillopsis zernowi } \\
\text { Dolgopolskaya, } 1948\end{array}$ \\
\hline & & & $\begin{array}{l}\text { Caromiobenella cf. helgolandica } \\
\text { (Claus, 1863) }\end{array}$ \\
\hline & & & Ca. pygmaea (Suárez-Morales, 2000) \\
\hline
\end{tabular}

\section{Results and Discussion}

\subsection{Species Diversity of the Monstrilloida}

Currently, there are about 155 nominal species in this copepod order, but the number of valid species is somewhat smaller. The taxonomic and nomenclatural problems exposed in different works $[7,8,14,32,33]$ have revealed many unlikely species records around the world, and especially a number of improbable cosmopolitan distributions. In earlier summaries of the group's diversity [7,8], 116-125 species were considered valid, with the following numbers of species in each then-recognized genus: Monstrilla (56 species), Cymbasoma (41), Monstrillopsis (12), and Maemonstrilla (7). Since then, the discovery of three additional genera of monstrilloids $[11,12,15]$ and many undescribed species, as well as the delineation of diverse species complexes, has resulted from recent exploration of unstudied areas as noted above. This has led to consistent growth in regional and world lists of Monstrilloida. The same can be expected in the MBS. Until very recently, only species of the genera Cymbasoma and Monstrilla had been confirmed as inhabiting MBS waters. Monstrillopsis zernowi, potentially a representative of a third genus, was described from the Black Sea [34], but it is probably a species of Monstrilla [35]. We do not know of any basis in the primary literature for the occasional mentions of Monstrillopsis dubia as a Mediterranean species in secondary sources $[29,36]$. The description of Monstrillopsis pontoeuxinensis from the Black Sea [35] has, however, confirmed the presence of this genus in the MBS region. In addition, the recently proposed [12] new and widespread genus Caromiobenella includes at least two MBS species, the former Monstrilla helgolandica and M. pygmaea, thereby adding a fourth genus to the currently known monstrilloid fauna of these seas (Table 1).

\subsection{Mediterranean-Black Sea Diversity of the Monstrilloida}

MBS waters represent a highly suitable environment for monstrilloids. They comprise a vast set of marine coastal ecosystems, with an irregular, deeply indented coastline, resulting in an extremely rich variety of coastal habitats. The Mediterranean alone is said to host $4 \%$ to $18 \%$ of the world's marine biodiversity $[37,38]$. In considering the world fauna of Monstrilloida, it has been suggested [7] that the regions with the highest known species richness were the European waters of the North Atlantic (32 species), the Caribbean Sea and Gulf of Mexico (24), the Mediterranean-Black Sea region (19), the Indonesia-MalaysiaPhilippines region (17), the waters around Japan (17), and the Brazil-Argentine area (16). An update of these data is needed because of the increasing number of species described 
in some of these regions. With this in mind, here, we review and update what is known concerning MBS monstrilloid diversity.

\subsection{MBS Monstrilloid Diversity, Historical Account}

The monstrilloid fauna of the MBS region has been investigated for almost 145 years. Four phases in the region's history of monstrilloid studies can be distinguished. The first preliminary phase (1877-1893) began with Kriczagin's (1877) [39] description of three supposedly new species: Monstrilla intermedia and M. pontica from five sites along the northeastern shore of the Black Sea and M. longissima from an unspecified Mediterranean site. Monstrilla intermedia was suppressed for purposes of priority in favor of M. grandis (for which see below) by the International Commission on Zoological Nomenclature [40]. Isaac (1975) [41] tentatively synonymized M. longissima with Cymbasoma longispinosum, but Grygier (1995) [14] considered the former "evidently a nomen nudum". Monstrilla pontica, currently Cymbasoma ponticum, has never been restudied and is excluded from our final checklist (Table 1) along with Kriczagin's other two species because its identity remains uncertain.

Subsequently, Cymbasoma herdmani was described in part from the Mediterranean Sea at Malta [42], where C. rigidum was also recorded [43]. The type series of C. herdmani included a specimen from North Wales as well as one from Malta; in context it seems likely that the former specimen served as the basis for the former paper's illustrations, but no lectotype has ever been selected. In British waters, C. herdmani was soon relegated to the synonymy of Monstrilla anglica [44-46], but the identity of the syntype from Malta remains unresolved [46]. Because M. anglica has never been recorded anew from the Mediterranean under its own name, there is a chance that the Maltese C. herdmani is not conspecific with it. Wilhelm Giesbrecht's (1893) [46] seminal work on the copepods of the Gulf of Naples, which has served as a principal reference work for all later researchers on MBS monstrilloids, included records from Naples of three species of Thaumaleus (T. longispinosus, T. claparedii, and T. reticulatus, all now in Cymbasoma) and two of Monstrilla (M. gracilicauda and $M$. longiremis). Giesbrecht thus brought the total number of nominal species recorded from the MBS region during this early period to 11, including those later judged invalid or doubtful (Table 1).

During the second phase (1895-1952), exploratory planktological work continued at various places in the MBS, but few taxonomic descriptions ensued. In the immediate postGiesbrecht period, Karavayev (1895) [47] described M. ostroumowi-possibly a synonym of C. rigidum [41,48] from Sevastopol Bay in the northeastern Black Sea; Graeffe (1900) [49] reported Cymbasoma rigidum from the Gulf of Trieste; M. longiremis and C. longispinosum were recorded from the Dalmatian coast of the Adriatic Sea at Tiesno (currently Tisno) and at Vodice and Rieka (currently Rijeka), respectively [50]; and C. thompsonii was reported from the Lagoon of Venice [51,52]. These early Adriatic records were later compiled [53]. In the meantime, Lo Bianco (1903) [54] reported C. longispinosum and unidentified monstrillids referred to as "Thaumaleus sp." from three sites in the vicinity of Capri, Italy, and Monstrilla grandis was reported from the Black Sea coast of Bulgaria [55]. Later, there were various reports [56-60] of C. longispinosum from "the Mediterranean", C. rigidum from Monaco, and M. helgolandica? (later with no question mark), Monstrilla longiremis, M. gracilicauda, M. sp., C. longispinosum, C. claparedii, and C. rigidum from the Bay of Algiers in North Africa [29,30]. Monstrilla longicornis and Monstrillopsis dubia were mentioned as Mediterranean species [30] while M. serricornis and M. grandis were included in a list of North African species, but we do not know what primary literature these records were based on, or what purported synonymies they may reflect. It is clear, however, that the latter authors treated $M$. serricornis as a synonym of $M$. helgolandica, thus as an invalid name.

According to a summary of the Adriatic plankton fauna [61], Monstrilla longiremis was recorded from the Adriatic at Trogir, Yugoslavia [62], and also from Kastela Bay [63], and C. longispinosum is mentioned as abundant in the northern Adriatic. Studies were then interrupted by war, after which Monstrillopsis zernowi was described [34] from Yarylgach 
Bay in western Crimea, northern Black Sea; this species is most likely actually a species of Monstrilla [35]. Dolgopolskaya (1948) [34] also recorded M. grandis, M. helgolandica, and C. longispinosum from there and/or Sevastopol Bay. Subsequently, C. longispinosum was reported from the Étang de Thau, a large lagoon on the French Mediterranean coast [64], and this long second historical phase closed with a list of North African copepods, including five nominal species of monstrilloids [30]. By our count, 12 nominal species, including eight not previously recorded and several judged by us as problematic, were recorded from the MBS during the second phase of study (Table 1).

The following third historical phase of monstrilloid studies in the MBS (1957-1986) was characterized by infrequent observations and little formal taxonomic treatment. Only four additional names are found among the ten species of monstrilloids recorded from the MBS in primary sources during this period (see Table 1). This phase opened with a mention of the occurrence of M. grandis in Varna Bay, Bulgaria [65], and with a widely known manual of Mediterranean planktology [31], in which just six monstrilloid species were illustrated (including again M. longicornis, the basis for which is unclear). Cymbasoma rigidum and C. thompsonii were reported from Constanta on Romania's Black Sea coast [48] and M. grandis was recorded from Marseilles [66]; M. leucopis was recorded from Villefranche [67], this last probably being a misidentification because $M$. leucopis appears to be restricted to Norway [26]. Monstrilla longiremis was reported from Yugoslavia's Bay of Mali Ston [68], and unidentified monstrilloids were reported from Livorno, Rapallo, and San Remo in northern Italy [69]. In the Levantine Basin, C. longispinosum, C. rigidum, and Monstrilla sp. were also reported [70]. In addition, M. longicornis and C. longispinosum were recorded from Marseilles [71].

Isaac's (1975) [40] introduction of the names Monstrilla tumorifrons and Monstrillopsis angustipes as self-declared nomina nuda in a key deserves special mention. Relatively full descriptions of both species were provided in an unpublished dissertation [72], and both came from Emborios Bay, Aegean Sea (i.e., the island of Chios, Greece). According to a recent nomenclatural review [73], the former name was later made available [22], but the latter remains unavailable. Pending a restudy of Isaac's material and validation of the name, Monstrillopsis angustipes is omitted from the final checklist herein (Table 1).

Razouls and Durand (1991) [36] closed this third period of study with an inventory of the then known Mediterranean copepod fauna. Of the 11 nominal species of monstrilloids they listed, three had not appeared to our knowledge in previous primary literature: Haemocera danae; Monstrilla conjunctiva, which is a supposed senior synonym of M. leucopis [74]; and Monstrillopsis dubia, a name perhaps carried forward from a previous work [29].

The most recent, fourth historical phase of monstrilloid research in the MBS (19922020) has featured a revival of detailed taxonomic work. Simple distribution records in different MBS locations include (presumably different) Monstrilla sp. at Tunis in North Africa [75], in a submarine cave of Italy's Salento Peninsula [76] and off the Kerch Peninsula of eastern Crimea [77], Monstrillopsis zernowi from a coastal bay near Sevastopol, Crimea [78], Monstrilla grandis from Toulon Bay, France [23], and Monstrilla sp. and unidentified monstrilloids respectively in plankton and in gut contents of pipefish at a total of four nearshore sites in Izmir Bay on the Aegean coast of Turkey $[79,80]$.

Revisionary work has so far focused on two older species. Redescriptions of both sexes of Cymbasoma tenue [21,23] were based on specimens from Toulon Bay, France; the latter paper also included a description of Monstrilla pygmaea (currently in Caromiobenella) from the same bay. Cymbasoma tumorifrons was also redescribed [22,24] based on original material from the island of Chios, Greece, and a newly caught female from Toulon Bay, while $C$. nicolettae was described from Toulon Bay [24]. Later, while studying monstrilloids from the Gulf of Trieste in the northern Adriatic Sea, females of $C$. tumorifrons from Greece and Toulon were reassigned to the new species $C$. mediterraneum, described from Trieste [28]. This was one of six new species from the Gulf of Trieste, five of Cymbasoma plus M. ghirardellii, that were described in the same work (see Table 1; another species remains undescribed), and the paper also reported very high local abundances of M. grandis. Other 
recent additions to the MBS monstrilloid fauna are the three new species described from the southern coast of the Black Sea at Sinop, Turkey: C. sinopense, C. turcorum, and Monstrillopsis pontoeuxinensis [35,81,82].

A map of all the MBS collection sites mentioned in the preceding historical review (Figure 1) shows that the sampling effort for monstrilloid copepods has been limited in the Mediterranean Sea largely to the French coast, the Bay of Algiers, the Gulf of Naples, and the Dalmatian coast and Trieste in the Adriatic Sea, in addition to scattered sites (notably around Crimea and at Sinop) in the Black Sea. Many coastal areas in both seas have produced only unidentified monstrilloids or remain completely unsurveyed for this group. The mainland Greek, Albanian, Spanish, Moroccan, Libyan, Egyptian, Israeli, Lebanese, southern Turkish, and Georgian coastlines, as well as all major Mediterranean islands, are blank. A recent comprehensive review of the Iberian non-calanoid copepods [83], including both the Atlantic and Mediterranean fauna, listed seven species each of Cymbasoma and Monstrilla based entirely on previous reviews. Among them, only C. nicolettae, which has been recorded from Toulon Bay in France, but not Spain [24], was explicitly presented as a Mediterranean form.

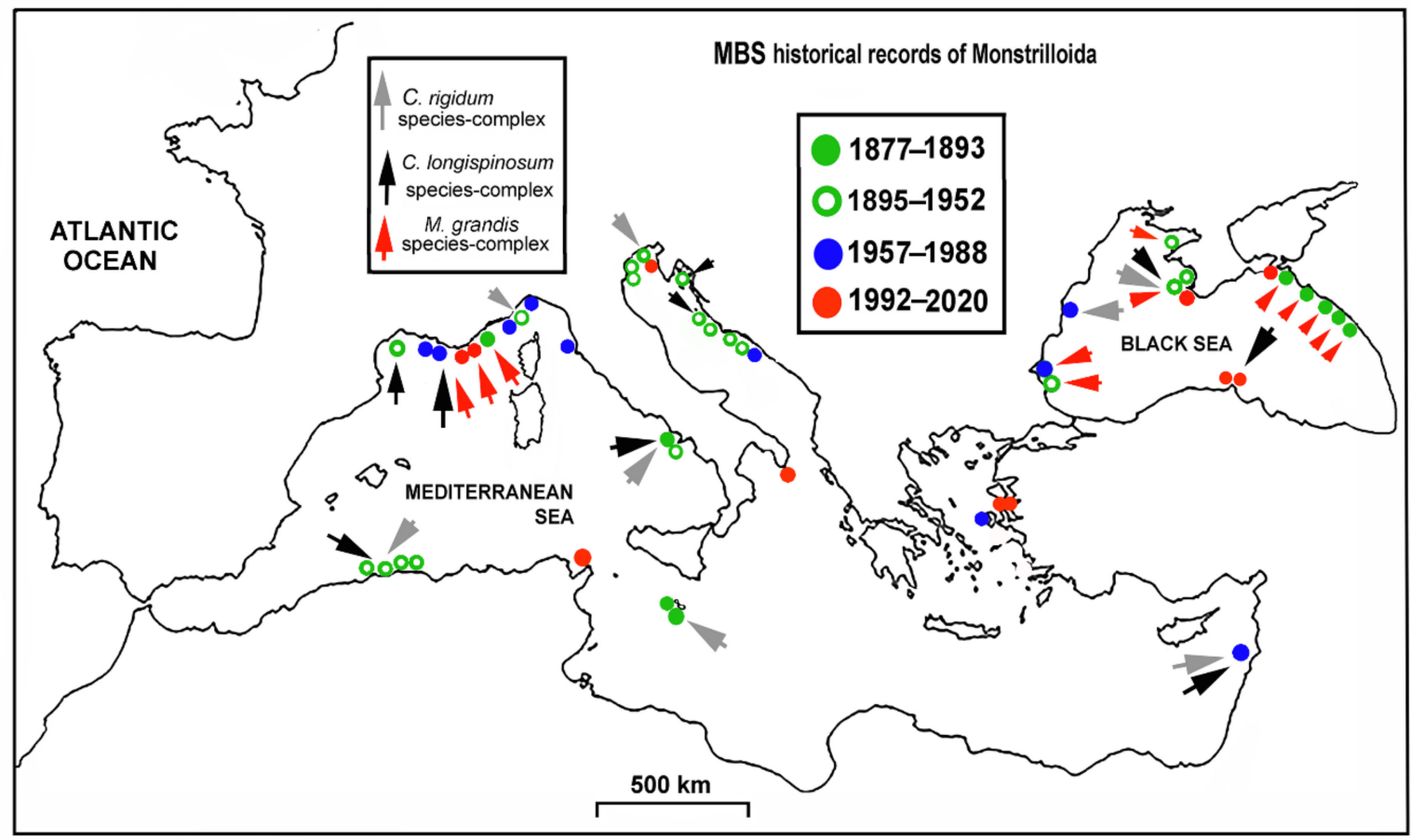

Figure 1. Historical and geographic distribution of MBS records of monstrilloid copepods between 1877 and 2020. Color dots refer to each of four historical periods. Black, gray, and red arrows represent the locations of species assignable to one of three species-complexes known to occur in the MBS region.

Much of the early literature on monstrilloids, at least up until Wilhelm Giesbrecht's (1893) [46] work, lacked detailed descriptions and illustrations of the species that were treated and named therein. In many cases, this has made subsequent identification difficult and untrustworthy, especially when a given nominal species has later been recorded from widely different geographic areas. Some such putative "species" have by now been recognized as species complexes $[7,8,17,84]$. The once supposedly cosmopolitan Monstrillopsis dubia is now deemed a complex of several different species [85]. A similar situation has been noted for Caromiobenella (formerly Monstrilla) helgolandica [12], Monstrilla grandis [17,82], and two species of Cymbasoma (C. longispinosum and C. rigidum; see below), all of which seemingly comprise many undescribed taxa. 


\subsection{Analysis of Selected Species-Groups}

\subsubsection{Cymbasoma longispinosum Species-Group}

After Bourne's (1890) [44] original description of C. longispinosum from the English Channel, this nominal species was recorded from many different parts of northern and western Europe, the MBS region, West Africa, the Red Sea and Arabian Gulf, India, Australia, the Philippines, Japan and Brazil $[14,86]$. Aside from the dubious proposition that a single monstrilloid species could be so widespread, some authors noted morphological differences between their specimens and the original description. It was later realized that this nominal species consists of a group of morphologically close species, each with a limited geographic distribution and subtle but consistent diagnostic distinctions $[81,86,87]$. Together with the previously described C. morii from Japan [33], they constitute a large species-group, eight additional members of which have recently been described [16,86,87]. As was recounted above and also shown in Figure 1, there have been many records of supposed C. longispinosum in different parts of the MBS region, but owing to a lack of descriptive information, their true identity and diversity remain unconfirmed. One new member of this species-group, (C. sinopense), was recently described from the Turkish Black Sea coast [81]; the same paper noted that this Black Sea population differs in various respects from supposed C. longispinosum in the Mediterranean, at least as described by W. Giesbrecht (1893) [46].

\subsubsection{Cymbasoma rigidum Species-Group}

This species was described by Thompson (1888) from the Canary Islands [42]. At least three distinct morphotypes have been distinguished among the many illustrated records of C. rigidum from different parts of the world [25]. This variability, the uncertain identity and unclear morphology of the original specimen, and the wide geographic scope of records of C. rigidum (for the MBS region, see Figure 1) sow doubt about whether all records pertain to one species, and if not, how widely the holotype's species is distributed. We suspect that this nominal species constitutes a species-complex with several undescribed taxa. Suárez-Morales (2006) [25] noted several differences between MBS C. rigidum and other European and Asian sites. Graeffe's (1900) [49] early record of C. rigidum from the Gulf of Trieste might actually pertain to either $C$. tergestinum or $C$. specchi, which were later described from that region [28]. In the Black Sea, M. ostroumowi has been recognized as a synonym of C. rigidum (e.g., [48]) but may possibly be a Black Sea or MBS endemic.

\subsubsection{Monstrilla grandis Species-Group}

This presumably widespread species was originally described by Giesbrecht (1891) from the southwestern Atlantic at $49^{\circ} \mathrm{S}, 65^{\circ} \mathrm{W}$, with no more than a brief diagnosis of the female [88]; both sexes were later described in detail based on this Atlantic material [46]. Suárez-Morales (2000) [23] provided a complementary description of the male based on specimens from Toulon Bay in the Mediterranean. In the meantime, as was noted above (see also Figure 1), purportedly the same species had been recorded from different areas of, first, the Black Sea (originally under the name $M$. intermedia), and later, the Mediterranean. As summarized by Grygier (1995) [14] and newly recorded by more recent authors (e.g., $[12,84,89,90]), M$. grandis has also been reported from other parts of the world: the northeastern Atlantic from the North Sea to Morocco, East Asian waters of Russia, China, Japan, and Korea; Barbados, Puerto Rico, and Costa Rica in the Caribbean region, and Brazil and Chile. The geographically closest records to the type locality are from coastal and offshore areas of Argentina [84,89,91]. Morphological differences have been detected among both males and females from different areas $[17,84]$, and morphometric differences exist in both sexes from the Adriatic Sea with respect to specimens recorded from other regions [28]. Such comparative data support the contention that undescribed species may be included in the nominal species M. grandis [28]. 


\section{Conclusions}

We count 20 species of monstrilloid copepods as confirmed inhabitants of the Mediterranean and Black seas (Table 1). Our chronologically categorized distribution map of records of Monstrilloida from this región (Figure 1) emphasizes in a graphic way just how small and scattered the well-sampled shorelines are, compared to the entire array of complex marine coastal systems present in these seas. New regional sampling efforts will surely result in a continued and highly significant lengthening of the lists of planktonic copepods, including monstrilloids, that occur there.

Author Contributions: Both authors contributed equally to the study's concept and design, the literature review, and the writing and editing of the text. All authors have read and agreed to the published version of the manuscript.

Funding: This research received no external funding. General support was provided by El Colegio de la Frontera Sur (ECOSUR) to ES-M, and MJG's work was enabled by support to National Taiwan Ocean University's Center of Excellence for the Oceans by the Featured Areas Research Center Program within the Taiwan Ministry of Education's Higher Education Sprout Project.

Institutional Review Board Statement: Not applicable.

Informed Consent Statement: Not applicable.

Data Availability Statement: The data presented in this study are available on request from the corresponding author.

Acknowledgments: E.S.-M. thanks the El Colegio de la Frontera Sur (ECOSUR) for allowing him to work from home during the past year.

Conflicts of Interest: The authors declare that they have no conflict of interest.

\section{References}

1. Khodami, S.; McArthur, J.V.; Blanco-Bercial, L.; Martinez Arbizu, P. Molecular phylogeny and revision of copepod orders (Crustacea: Copepoda). Sci. Rep. 2017, 7, 9164. [CrossRef]

2. Boxshall, G.A.; Halsey, S.H. An Introduction to Copepod Diversity; The Ray Society: London, UK, 2004; Part II; pp. 422-966.

3. Belmonte, G. Calanoida (Crustacea: Copepoda) of the Italian fauna: A review. Eur. Zool. J. 2018, 85, 273-289. [CrossRef]

4. Razouls, C. Diversité et répartition géographique chez les copépodes pélagiques. 2. Platycopioida, Misophrioida, Mormonilloida, Cyclopoida, Poecilostomatoida, Siphonostomatoida, Harpacticoida, Monstrilloida. Ann. Inst. Océanogr. N. Sér. 1996, 72, 1-149.

5. Razouls, C.; Desreumaux, N.; Kouwenberg, J.; de Bovée, F. Biodiversity of Marine Planktonic Copepods (Morphology, Geographical Distribution and Biological Data); Sorbonne Univ.-CNRS: Paris, France, 2005-2021; Available online: http:/ / copepodes.obs-banyuls. fr/en (accessed on 15 February 2021).

6. Suárez-Morales, E. An aggregation of monstrilloid copepods in a western Caribbean reef area: Ecological and conceptual implications. Crustaceana 2001, 74, 689-696. [CrossRef]

7. Suárez-Morales, E. Diversity of the Monstrilloida (Crustacea: Copepoda). PLoS ONE 2011, 6, e22915. [CrossRef] [PubMed]

8. Suárez-Morales, E. Crustacea Orden Monstrilloida Revista IDE@ (Ibero-Diversidad Entomológica @ccesible). SEA Soc. Ent. Arag. 2015, 20, 1-12.

9. Walter, T.C.; Boxshall, G.A. World of Copepods Database. Monstrilloida. Accessed 2021-02-25 through: World Register of Marine Species 2021. Available online: http:/ / marinespecies.org/aphia.php?p=taxdetails\&id=1106 (accessed on 11 February 2021).

10. Grygier, M.J.; Ohtsuka, S. A new genus of monstrilloid copepods (Crustacea) with anteriorly pointing ovigerous spines and related adaptations for subthoracic brooding. Zool. J. Linn. Soc. 2008, 152, 459-506. [CrossRef]

11. Suárez-Morales, E. A new genus of the Monstrilloida (Copepoda) with large rostral process and metasomal spines, and redescription of Monstrilla spinosa Park, 1967. Crustaceana 2019, 92, 1099-1112. [CrossRef]

12. Jeon, D.; Lee, W.; Soh, H.Y. New genus and two new species of monstrilloid copepods (Copepoda: Monstrillidae): Integrating morphological, molecular, phylogenetic, and ecological evidence. J. Crustac. Biol. 2018, 38, 45-65. [CrossRef]

13. Jeon, D.; Lim, D.; Lee, W.; Soh, H.Y. First use of molecular evidence to match sexes in the Monstrilloida (Crustacea: Copepoda), and taxonomic implications of the newly recognized and described, partly Maemonstrilla-like females of Monstrillopsis longilobata Lee, Kim \& Chang, 2016. Peer J. 2018, 6, e4938.

14. Grygier, M.J. Annotated chronological bibliography of Monstrilloida (Crustacea: Copepoda). Galaxea 1995, 12, 1-82.

15. Suárez-Morales, E.; McKinnon, A.D. The Australian Monstrilloida (Crustacea: Copepoda) I. Monstrillopsis Sars, Maemonstrilla Grygier \& Ohtsuka, and Australomonstrillopsis gen. nov. Zootaxa 2014, 3779, 301-340. [PubMed]

16. Suárez-Morales, E.; McKinnon, A.D. The Australian Monstrilloida (Crustacea: Copepoda) II. Cymbasoma Thompson, 1888. Zootaxa Monogr. 2016, 4102, 1-129. [CrossRef] 
17. Chang, C.Y. Two new records of monstrilloid copepods (Crustacea) from Korea. Anim. Syst. Evol. Div. 2014, 30, 206-214. [CrossRef]

18. Lee, J.; Chang, C.Y. A new species of Monstrilla Dana, 1849 (Copepoda: Monstrilloida: Monstrillidae) from Korea, including a key to species from the northwest Pacific. Zootaxa 2016, 4174, 396-409. [CrossRef]

19. Lee, J.; Kim, D.; Chang, C.Y. Two new species of the genus Monstrillopsis Sars, 1921 (Copepoda: Monstrilloida: Monstrillidae) from South Korea. Zootaxa 2016, 4174, 410-423. [CrossRef]

20. Jeon, D.; Lee, W.; Soh, H.Y.; Eyun, S.-I. A new species of Monstrillopsis Sars, 1921 (Copepoda: Monstrilloida) with an unusually reduced urosome. Diversity 2020, 19, 9. [CrossRef]

21. Suárez-Morales, E.; Riccardi, N. Redescription and first record of Cymbasoma tenue (Isaac, 1975) (Copepoda: Monstrilloida) in the Mediterranean Sea. Proc. Biol. Soc. Wash. 1997, 110, 99-106.

22. Suárez-Morales, E. Redescription of the male of Cymbasoma tumorifrons (Isaac, 1975) from the Mediterranean Sea (Copepoda: Monstrilloida). Arthrop. Sel. 1999, 8, 67-71.

23. Suárez-Morales, E. Taxonomic report on some monstrilloids (Copepoda, Monstrilloida) from Toulon Bay, France. Bull. Inst. Royal Sci. Nat. Belg. Biol. 2000, 70, 107-118.

24. Suárez-Morales, E. A new species of Cymbasoma (Copepoda: Monstrilloida) from the Mediterranean Sea with remarks on the female of C. tumorifrons (Isaac). Mitt. Mus. Naturk. Berlin Zool. Reihe 2002, 78, 87-96. [CrossRef]

25. Suárez-Morales, E. Validation and redescription of Cymbasoma germanicum (Timm) (Crustacea: Copepoda: Monstrilloida) from Helgoland with comments on C. rigidum Thompson. Helgol. Mar. Res. 2006, 60, 171-179. [CrossRef]

26. Suárez-Morales, E. On the taxonomic status of Monstrilla leucopis Sars (Crustacea: Copepoda: Monstrilloida) from Norway, with comments on the male of M. longiz Giesbrecht. Zootaxa 2010, 2510, 55-67. [CrossRef]

27. Suárez-Morales, E.; Bello-Smith, A.; Palma, S. A revision of the genus Monstrillopsis Sars (Crustacea: Copepoda: Monstrilloida) with description of a new species from Chile. Zool. Anz. 2006, 245, 95-107. [CrossRef]

28. Suárez-Morales, E.; Goruppi, A.; de Olazabal, A.; Tirelli, V. Monstrilloids (Crustacea: Copepoda) from the Mediterranean Sea (Northern Adriatic Sea), with a description of six new species. J. Nat. Hist. 2017, 51, 1795-1834. [CrossRef]

29. Rose, M. Copépodes pélagiques. Faune Fr. 1933, 26, 1-374.

30. Rose, M.; Vaissière, R. Catalogue préliminaire des Copépodes de l'Afrique du Nord. Bull. Soc. Hist. Nat. Afrique Nord 1952, 43, 113-136.

31. Trégouboff, G.; Rose, M. Manuel de Planctonologie Méditerranéenne; Centre National de la Recherche Scientifique: Paris, France, 1957; Volumes I-II, pp. 1-590.

32. Grygier, M.J. Identity of Thaumatoessa (Thaumaleus) typica Krøyer, the first described monstrilloid copepod. Sarsia 1993, 78, 235-242. [CrossRef]

33. Grygier, M.J. Nomenclature, redescription and new record of Cymbasoma morii Sekiguchi, 1982 (Monstrilloida). Hydrobiologia 1994, 292, 23-29. [CrossRef]

34. Dolgopolskaya, M.A. K faune Monstrillidae Chernogo morya. Trud. Zool. Inst. Akad. Nauk SSSR. 1948, 7, 177-183. (In Russian)

35. Suárez-Morales, E.; Üstün, F. Report on some monstrilloids (Crustacea: Copepoda: Monstrilloida) from Turkey, with description of two new species. Cah. Biol. Mar. 2018, 59, 547-562.

36. Razouls, C.; Durand, J. Inventaire des copépodes planctoniques Méditerranéens. Vie Milieu 1991, 41, 73-77.

37. Coll, M.; Piroddi, C.; Steenbeek, J.; Kaschner, K.; Lasram, F.B.R.; Aguzzi, J.; Ballesteros, E.; Bianchi, C.N.; Corbera, J.; Dailianis, T.; et al. The biodiversity of the Mediterranean Sea: Estimates, patterns, and threats. PLoS ONE 2010, 5, e11842. [CrossRef] [PubMed]

38. Gabrié, J.; Marbà, N.; Duarte, C.M. Mediterranean seagrass vulnerable to regional climate warming. Nat. Clim. Chang. 2012, 2, 821-824. [CrossRef]

39. Kriczagin, N.A. Account of an excursion to the NW coast of the Black Sea, carried out as a mission of the Kiev Society of Naturalists in the summer of 1874. Zap. Obshch. Estestvoispyt. 1877, 5, 1-56. (In Russian)

40. Melville, R.V. Monstrilla intermedia Kriczagin, 1877 (Copepoda) suppressed. Bull. Zool. Nomencl. 1981, 38, 107-109.

41. Isaac, M.J. Copepoda, Suborder: Monstrilloida. Fich. Ident. Zooplankt. 1975, 144-145, 1-10.

42. Thompson, I.C. Second report on the Copepoda of Liverpool Bay. Proc. Liverpool Biol. Soc. 1888, 2, 63-71, pls. I-II.

43. Thompson, I.C. Copepoda of Madeira and the Canary Islands, with descriptions of new genera and species. J. Linn. Soc. London Zool. 1888, 20, 145-156. [CrossRef]

44. Bourne, G.C. Notes on the genus Monstrilla Dana. Quart. J. Microscop. Sci. 1890, 30, 565-578.

45. Thompson, I.C. Monstrilla and the Cymbasomatidae. Proc. Trans. Liverpool Biol. Soc. 1890, 4, 115-124.

46. Giesbrecht, W. Systematik und Faunistik der pelagischen Copepoden des Golfes von Neapel und der angrenzenden MeeresAbschnitte. Fauna Flora Golfes Neapel Monogr. 1893, 19, 1-831, 54 plates.

47. Karavayev, V. Material towards the fauna of copepods (Copepoda) of the Black Sea. Zap. Kiyevsk. Obshch. Estestvoispyt. 1895, 14, 117-174. (In Russian)

48. Porumb, F.I. Contributii la cunoasterea familiei Monstrillidae din dreptul litoralului rominesc al Marii Negre. Com. Acad. Republ. Pop. Rom. 1961, 11, 1223-1231.

49. Graeffe, E. Uebersicht der Fauna des Golfes von Triest nebst Notizen über Vorkommen, Lebenweise, Erscheinungs- und Laichzeit der einzelen Arten. V. Crustacea. Arb. Zool. Inst. Univ. Wien Zool. Stat. Triest 1900, 13, 33-80. 
50. Car, L. Planktonproben aus dem Adriatischen Meere und einigen süssen und brakischen Gewässern Dalmatiens. Zool. Anz. 1902, 25, 601-605.

51. Grandori, R. I Copepodi. In Richerche sul plancton dell Laguna Veneta; Carazzi, D., Grandori, R., Eds.; University of Padova: Padova, Italy, 1912; pp. 1-40.

52. Grandori, R. Studi biologici sul Plancton della Laguna Veneta e dell'alto Adriatico. Atti Acad. Sci. Ven. Trent. Istr. 1914, 3, $149-171$.

53. Pesta, O. Die Planctoncopepoden der Adria. Zool. Jahrb. 1920, 43, 471-659.

54. Lo Bianco, S. Le pesche aissali eseguire de FA Krupp col yacht Puritan nelle adiacensze di Capri ed in altre localitá del Mediterraneo. Mitt. Zool. Stat. Neapel 1903, 16, 109-128.

55. Chichkoff, G. Contribution a l'étude de la faune de la Mer Noire. Animaux récoltés sur les cotes bulgares. Arch. Zool. Expér. Gén. 1912, 10, 29-31.

56. Rose, M. Notes faunistiques sur les Copépodes pélagiques des côtes de France. Bull. Soc. Zool. France 1926, $51,134-138$.

57. Rose, M. Le plancton de la baie d'Alger pendant le mois de décembre (Suite). Bull. Soc. Hist. Nat. Afrique Nord 1926, $17,44-48$.

58. Rose, M. Observations préliminaires sur le plankton de la région d'Alger. Bull. Trav. Sta. Aquicult. Pêche Castiglione 1927, 1, 129-164.

59. Rose, M. Recherches preliminaires sur le Plankton de profundeur de la Baie d'Alger. Bull. Trav. Sta. Aquicult. Pêche Castiglione 1934, 1, 43-81.

60. Rose, M. Recherches complémentaires sur les Copépodes Pélagiques de la Baie d'Alger. Bull. Soc. Hist. Nat. Afrique Nord 1934, 25, 145-148.

61. Hure, J.; Kršinić, F. Planktonic copepods of the Adriatic Sea. Spatial and temporal distribution. Natur. Croat. 1998, 7, 1-135.

62. Mužinić, S. Ekološka Ispitivanja na Jadranskoj Srdeli (Clupea pilchardus Walb.); Štamparija Dragomira Popovića: Belgrade, Yugoslavia, 1936; pp. 1-109.

63. Gamulin, T. Qualitative and quantitative research of planktonic copepods in the eastern coastal waters of the central Adriatic over the years 1936/37. Yugosl. Acad. Sci. Arts 1939, 22, 97-180, (not seen).

64. Mathias, P.; Euzet, L. Sur les Copépodes planctoniques de l'Étang de Thau. Bull. Soc. Hist. Nat. Toulouse 1951, 86, 184-188.

65. Rusev, B.; Dimov, I. Qualitative and quantitative studies of the zooplankton of Varna Bay. Nauch.-Izsled. Inst. Ribarst. Rib. Promishl. 1957, 1, 79-109.

66. Gaudy, R. Biologie des Copépodes pélagiques de Golfe de Marseille. Rec. Trav. Stat. Mar. d’Endoume 1962, 27, 93-184.

67. Djordjevic, M. Observation sur les Copépodes pélagiques en rade de Villefranche de mars à août 1962. Comm. Int. Explor. Scient. Mer Méd. Monaco. Rapp. Procés-Verb. Réun. 1963, 17, 575-580.

68. Buljan, M.; Hure, J.; Pucher-Petković, T. Hydrographic and productivity conditions in the Bay of Mali Ston. Report on the work made during the dam construction of the Trebišnjica Hydroelectric Power Plant. Acta Adriat. 1973, 15, 3-60.

69. Basso, M.P.; Cevasco, M.G.; Della Croce, N.; Picone, P. Caratteristiche ecologiche e popolamento zoplanctonico in ambienti portuali del Mar Ligure a Alto Tirreno. Univ. Genova Catt. Idrobiol. Pescicolt. Fac. Sci. Fis. Mat. Natur. Rap. Tec. 1980, 12, $2-48$.

70. Lakkis, S. On the presence of some rare copepods in the Levantine Basin. Crustaceana Suppl. 1984, 7, $286-304$.

71. Citarella, G. Les Copépodes des eaux portuaires de Marseille (Méditerranée nord-occidentale). Syllogeus 1986, 58, $276-282$.

72. Isaac, M.J. Studies on Planktonic Arthropods. Ph.D. Thesis, University College of Swansea, University of Wales, Swansea, UK, 1974.

73. Grygier, M.J.; Suárez-Morales, E. Recognition and partial solution of nomenclatural issues involving copepods of the family Monstrillidae (Crustacea: Copepoda: Monstrilloida). Zootaxa 2018, 4486, 497-509. [CrossRef]

74. Razouls, C. Bilan Actuel des Copépodes Planctoniques Marins et des eaux Saumâtres. Corrections et Complements; Laboratoire Arago: Banyuls-sur-Mer, France, 1991; pp. 1-240.

75. Annabi-Trabelsi, M.N.; Daly-Yahia, M.S.; Romdhane, A.; Ben Maïz, N. Seasonal variability of planktonic copepods in Tunis North Lagoon (Tunisia, North Africa). Cah. Biol. Mar. 2005, 46, 325-333.

76. Onorato, M.; Belmonte, G. Submarine caves of the Salento Peninsula: Faunal aspects. Thal. Salent. 2017, $39,47-72$.

77. Zaremba, N.B. Zooplankton of the south-eastern part of the Kerch Peninsula in the summer and autumn seasons of 2015. Trudy YUgNIRO 2017, 54, 77-81, (In Russian with English summary).

78. Galagovets, E.A.; Prusova, I.Y. First observations of tumor-like anomalies in platonic copepods in the Crimean coastal waters. J. Siber. Fed. Univ. Biol. 2016, 4, 441-451. [CrossRef]

79. Pulat, İ.; Özel, İ. The plankton fauna of the northern lagoonary system of Izmir Bay. EU J. Fish. Aquat. Sci. 2003, 20, 399-403.

80. Gurkan, S.; Sever, T.M.; Taskavak, E. The biometric analysis of pipefish species from Çamalti Lagoon (İzmir Bay, Aegean Sea). EU J. Fish. Aquat. Sci. 2008, 25, 53-56.

81. Üstün, F.; Terbiyik Kurt, T.; Suárez-Morales, E. A new species of Cymbasoma (Copepoda, Monstrilloida) from the northern coast of Turkey (Black Sea) with comments on the C. longispinosum species-group. Crustaceana 2014, 87, 1393-1410. [CrossRef]

82. Suárez-Morales, E.; Üstün, F. Validation of Cymbasoma turcorum and Monstrillopsis pontoeuxinensis, two monstrilloids from Turkey described by Suárez-Morales \& Üstün in 2018 (Crustacea: Copepoda: Monstrilloida). Zootaxa 2020, 4779, $149-150$.

83. Vives, F.; Shmeleva, A.A. Crustacea, Copépodos Marinos II. In Non Calanoida. Fauna Ibérica; CSIC: Madrid, Spain, 2010; Volume 33, pp. 1-486.

84. Suárez-Morales, E.; Carrillo, A.; Morales-Ramírez, A. Report on some monstrilloids (Crustacea: Copepoda) from a reef area off the Caribbean coast of Costa Rica, Central America with description of two new species. J. Nat. Hist. 2013, 47, 619-638. [CrossRef] 
85. Suárez-Morales, E.; Ivanenko, V.N. Two new species of Monstrillopsis Sars (Copepoda: Monstrilloida) from the White Sea and Norway, with comments on M. dubia Scott. Arctic 2004, 57, 37-46. [CrossRef]

86. Suárez-Morales, E.; Dias, C.O.; Costa-Bonecker, S.L. Discovery of the female Cymbasoma rochai Suárez-Morales \& Dias, 2001 (Copepoda: Monstrilloida: Monstrillidae), the first Brazilian member of the C. longispinosum species-group. Crustaceana 2020, 93, 1091-1101.

87. Suárez-Morales, E.; Vásquez-Yeomans, L.; Santoya, L. A new species of the Cymbasoma longispinosum species-group (Copepoda, Monstrilloida, Monstrillidae) from Belize, western Caribbean Sea. Rev. Mex. Biodiv. 2020, 91, 1-11. [CrossRef]

88. Giesbrecht, W. Elenco dei Copepodi pelagici raccolti dal tenente di vascello Gaetano Chierchia durante el viaggio della R. Corvetta "Vettor Pisani" negli anni 1882-1885, e dal tenente di vascello Francesco Orsini nel Mar Rosso, nel 1884. Rend. Sed. R. Acad. Lincei 1891, 7, 474-481.

89. Dias, C.O.; Bonecker, S.L.C. Study of Monstrilloida distribution (Crustacea, Copepoda) in the Southwest Atlantic. Pan-Amer. J. Aquat. Sci. 2007, 2, 270-278.

90. Bonk, T.V.; Sushkevich, N.S.; Lozovoy, A.P. The first foundation the Monstrilloida (Copepoda) species in Okhotsk Sea near Kamchatka shore. In Conservation of biodiversity of Kamchatka and Coastal Waters: Materials of the XX International Scientific Conference, 150th Anniversary of V.L. Komarov's Birthday; Tokranov, A.M., Ed.; Kamchatpress: Petropavlovsk-Kamchatski, Russia, 2019; pp. 157-159. (In Russian)

91. Ramírez, F.C. Nuevas localidades para Monstrilla grandis Giesbrecht 1892 y Monstrilla helgolandica Claus 1863 (Copepoda, Monstrilloida) hallados en aguas de la plataforma Argentina. Physis Buenos Aires 1971, 30, 377-383. 